\title{
STATE OF THE ART OF SCIENTIFIC LITERATURE ON Hancornia speciosa: TRENDS AND GAPS ${ }^{1}$
}

\author{
LUCIANE MADUREIRA DE ALMEIDA², CÁSSIA APARECIDA NOGUEIRA ${ }^{3}$, \\ PEDRO PAULINO BORGES ${ }^{4}$, ANGÉLICA DAIANE LEMOS DO PRADO ${ }^{5}$, \\ PABLO JOSÉ GONÇALVES 6
}

\begin{abstract}
The economic and scientific interest in Hancornia speciosa (mangabeira) has been growing in recent years, mainly due to the marketing of fruit and extraction of natural compounds with high pharmacological potential. In this study, a scientometric survey about mangabeira was carried out in order to promote and direct future studies on the species. As a result, low scientific productivity associated with this species was found, with only 131 articles published in the last 69 years. In addition, this study identified some trends in bibliographic production on mangabeira, among them: the increasing number of articles over the years; scientific dissemination in nationwide journals; the main focus of this study is associated with agronomic studies; the experimental approach is more frequent and usually associated with populations of restricted geographical distribution; and the scientific production is mainly from education institutions. Furthermore, this study also allowed the identification of some gaps in knowledge about mangabeira, among them the difficulty in describing and characterizing botanical lines; lack of analysis of the genetic diversity of widely distributed populations; lack of management and conservation projects for the species; lack of description of cultivation, collection and preservation techniques of fruits; and lack of identification of natural compounds responsible for its pharmacological activity. It is expected that the data generated in this study will serve to direct future studies on $H$. speciosa.
\end{abstract}

Index terms: mangabeira, native fruit, scientometrics.

\section{ESTADO DA ARTE DA LITERATURA CIENTÍFICA SOBRE Hancornia speciosa: TENDÊNCIAS E LACUNAS}

\begin{abstract}
RESUMO-O interesse econômico e científico sobre Hancornia speciosa (mangabeira) vem crescendo nos últimos anos, devido principalmente à comercialização de seu fruto e extração de compostos naturais com alto potencial farmacológico. Neste estudo, foi realizado um levantamento cienciométrico sobre a mangabeira, com o objetivo de fomentar e direcionar futuras pesquisas sobre a espécie. Como resultado, verificou-se a baixa produtividade científica a respeito da espécie, com a publicação de apenas 131 artigos nos últimos 69 anos. Além disso, o presente estudo identificou algumas tendências na produção bibliográfica sobre a mangabeira, com destaque para: o aumento do número de artigos ao longo dos últimos anos; o fato de a divulgação científica ser realizada principalmente em revistas de âmbito nacional; a abordagem experimental ser mais frequente do que a abordagem teórico-descritiva; os trabalhos experimentais serem geralmente associados às populações de distribuição geográfica restrita; e a produção científica ser proveniente, principalmente, de Instituições de Ensino Superior. Por outro lado, este estudo também permitiu a identificação de algumas lacunas no conhecimento sobre a mangabeira, entre as quais se destacam: a dificuldade em descrever e caracterizar as linhagens botânicas; a falta de análise da diversidade genética de populações de ampla distribuição geográfica; a carência de projetos de manejo e de conservação da espécie; a falta de descrição de técnicas de cultivo, coleta e conservação de frutos; e a ausência da identificação dos compostos naturais responsáveis pela atividade de farmacógica. Espera-se que os dados gerados nesta pesquisa possam ser usados para direcionar futuros estudos sobre a planta.
\end{abstract}

Index terms: Cienciometria, frutífera nativa, mangabeira.

\footnotetext{
1(Paper 182-15). Received July 15, 2015. Accepted November 16, 2015.

${ }^{2}$ Biologist, PhD in Genetics, Professor at Universidade Estadual de Goiás - Câmpus Anápolis de Ciências Exatas e Tecnológicas, Anápolis, GO, Brazil. Correspondence author: E-mail: luciane.almeida@ueg.br

${ }^{3}$ Biologist, Master in Recursos Naturais do Cerrado by Universidade Estadual de Goiás - Câmpus Anápolis de Ciências Exatas e Tecnológicas, Anápolis, GO, Brazil; E-mail: cassia_can10@hotmail.co.uk

${ }^{4}$ Biologist, Master in Recursos Naturais do Cerrado by Universidade Estadual de Goiás - Câmpus Anápolis de Ciências Exatas e Tecnológicas, Anápolis, GO, Brazil; E-mail: pedropaulinoborges_@hotmail.com

${ }^{5}$ Graduated in Forestry Engineering at Universidade Estadual de Goiás - Câmpus Ipameri, GO, Brazil; E-mail: pradoadl@hotmail.com ${ }^{6}$ Physicist, PhD in Applied Physics to Medicine and Biology, Professor at Physics Institute of Universidade Federal de Goiás, UFG, Goiânia, Brazil; E-mail:pablo@if.ufg.br
} 


\section{INTRODUCTION}

Hancornia speciosa, commonly known as mangabeira, is a native species of various ecosystems by adapting to different types of soil and climate (SILVA JR, Ledo, 2006). In Brazil, its distribution extends along the Atlantic Coast from Amapá and Pará, in the coastal plains and coastal lowlands of northeastern Brazil up to the state of Espírito Santo, throughout Central Brazil's Cerrado to the Pantanal region (Lederman et al., 2000). In Brazil's Cerrado, mangabeira is restricted to certain environments, occurring mainly in high steepness places such as slopes, being unsuitable for mechanized agriculture (Rezende et al., 2003).

According to botanical classification, mangabeira belongs to the genus Hancornia, which is considered monotypic, i.e., its unique species is $H$. speciosa Gomes. It belongs to class Dicotyledoneae, order Gentianales, family Apocynaceae, and to species $H$. speciosa, which has six varieties: $H$. speciosa variety speciosa, maximilliani, lundii, cuyabensis, gardnerie and pubescens (Monachino, 1945).

The economic and scientific interest in mangabeira culture has been growing in recent years, and the main reason is the marketing of the fruit, which is called mangaba. This fruit can be consumed fresh or processed in the form of jelly, sweet, ice cream, juice, soft drink, liquor, wine and syrup (SILVA JR, LEDO, 2006). In addition to fruits, other important by-products with pharmacological potential can be extracted from this plant. For example, studies have shown that $H$. speciosa leaves have bioactive compounds that effectively control blood pressure (SILVA et al 2011) and diabetes (PEREIRA et al, 2015.); and the latex of this species has anti-inflammatory (MARINO et al., 2011), angiogenesis action (ALMEIDA et al., 2014) and osteogenic action (FLORIANO et al., 2016).

Despite the great food and pharmaceutical potential, the species is at risk of disappearing, especially from Cerrado regions, due to the expansion of agricultural borders and intense agricultural activity (MANICA, 2002). This scenario requires an investigation of the current state of the art of scientific literature on mangabeira, which may be done through a scientometric study.

Scientometrics can be defined as a quantitative or qualitative study that aims to identify patterns or trends that may exist in publications of a given field of scientific investigation (ENSSLIN et al., 2015). In addition, it serves to identify which areas of study need greater attention in a given field of expertise (GUPTA et al., 2014). Thus, the aim of this work was to perform a scientometric survey on species $H$. speciosa. Specific aims were: i) to assess scientific production over the years; ii) to assess the quality of bibliographic production by analyzing the number of citations and the impact factor of journals; iii) to define the main areas of knowledge covered by published articles; iv) to understand the main types of studies (i.e., theoretical / descriptive and experimental); v) to verify the study scale (i.e., local, regional or national); vi) to determine the main institutions that published articles on mangabeira; vii) to analyze the origin of the first author and the place where the study was conducted.

\section{MATERIAL AND METHODS}

Articles on $H$. speciosa were obtained from three databases: ISI Web of Science, SCOPUS and Scielo, published in the period from 1945 to 2014. A literature search was performed using title, abstract and keywords containing the words Mangabeira* OR mangaba* OR "Hancornia speciosa" OR "Hancornia speciosa Gomes*" OR "H. speciosa" OR "H. speciosa Gomes*". The analysis was conducted to obtain the following information: 1) date of publication; 2) name of the journal; 3) impact factor of the journal; 4) number of citations; 5) areas of concentration of studies; 6) type of scientific article; 7) geographic scope of the study; 8) country of the first author; and 9) scientific production obtained by type of institution. After obtaining the published articles, screening was performed for identification and removal of publications that appeared in more than one database. After separation, abstracts and / or full articles were read. While reading, articles out of the study theme were excluded, for example, in cases where the word mangabeira referred to the name of a particular author or study place, but was not related to the species. The statistical analysis of results was performed using the $\mathrm{R}$ software version 3.0.1 (R Development Core Team, 2013).

\section{RESULTS AND DISCUSSION}

The initial literature search in different databases identified a total of 637 articles published on the subject from 1945 to 2014. Of this total, 287 articles were excluded after screening, which were repeated in more than one database and 219 articles that did not address the theme. Finally, 131 
articles remained in the search and served as basis for this research. The first analysis was related to bibliographic production over time. As a result, it was observed that there was a significant increase (Pearson's correlation $\mathrm{R}=0.51$, significance level $\mathrm{P}=0.007)$ in the number of articles over time. However, even with the increasing number of published articles, the number is still considered low. A chronological analysis has shown that the scientific interest in this species is recent. The first publications occurred before 1950 and from then, there was a gap of 43 years without publications on the subject. Only around 2010, a significant increase in the number of publications was observed (Figure 1).

The low number of articles on $H$. speciosa indicates need to increase research on mangabeira, as there are many gaps in the scientific knowledge on this species. The deficiencies on the knowledge on this species appear to have minimized with the increasing number of scientific articles published in recent years. This increase may be the result of the disclosure of results on the economic potential of this species, both in the area of production and fruit conservation (CAMPOS et al, 2011; CONAB, 2014) as in the area of use of compounds in pharmacology (SILVA et al. 2011; MARINO et al, 2011; ALMEIDA et al, 2014; PEREIRA et al, 2015). Increased knowledge about the economic potential of this species will help disclosing its economic importance, thus contributing to increase its cultivation and conservation (CALIMAN et al., 2010). On the other hand, the low number of studies on the species is concerning, because according to Manica (2002), the species is threatened with extinction. The extinction of $H$. speciosa would lead to loss of the previously described potential and other uses that could be discovered if more studies on this species had been published.

Another aspect analyzed in this article was the quality of bibliographic production. This parameter was obtained by evaluating the number of citations of articles on the subject and the impact factor of journals. As a result, it was observed that studies on $H$. speciosa are little cited, and that journals that publish studies on this topic have broad access and nationwide broadcasting. The number of citations ranged from 0 to 113 with mean of $8.9 \pm 16.44$, while the impact factor ranged from 0.08 to 3.53 with mean of $1.18 \pm 1.05$ (Figure 2 ).

The journal that published the highest number of articles on the topic was the Brazilian Journal of Fruit Growing, with 15 published articles (Figure 2). Other journals that frequently published on the theme were the Brazilian Journal of Agricultural Research, with eight articles, followed by journals Biosciense Journal and Acta Scientiarum Agronomy, with seven articles each. The above journals are of the agronomy area and are focused on the management of species and production of fruits, both for economic purposes and also for purposes of species conservation.

Another question that this article responded was about the main study area of the species. The result showed that agronomic studies are the most frequent, followed by food engineering studies (Figure 3). The larger number of studies with agronomic approach is justified by the fact that the main commercial interest of the plant is the fruit and its derivatives (SOUZA, 2007).

According to the National Supply Company (2014), the production of mangaba in Brazil in 2012 was approximately 680 tons. This is a significant production if we consider that there are few commercial mangabeira plantations in Brazil and in most of the producing states, fruit production coming into the market and processing industries is extractive (LEDERMAN et al., 2000). Regardless of origin, another problem is the lack of production processing techniques, and in Brazil, most of mangaba harvested is sold in the fresh form, which does not add commercial value to this culture. Another obstacle to be discussed in relation to the extractive activity of mangaba is that fruits do not have quality and supply on a regular basis. This causes problems for processing and marketing intensification, either because there is no expectation of volume, because quality (size, color, flavor, ripeness) is variable, or because there are no adequate post-harvest procedures (MOTA et al., 2008).

Also in relation to production, a positive aspect is the commercial value of the fruit in the market. A study conducted in Sergipe showed that mangaba is a fruit that knows no downturns in its price (VIEIRA-NETO, 2007). It is estimated that one can obtain in a well-conducted planting, an annual net income of $\mathrm{R} \$ 6.000,00$ to $\mathrm{R} \$ 8.000,00$ per hectare, which is higher than the gain provided by most traditional crops. Moreover, the fruit has aroused great popular interest, and is the pulp most sold by industries in the state, accounting for $25 \%$ of sales. These characteristics make mangabeira one of the most profitable crops in the state of Sergipe (VIEIRA NETO, 2007).

It is noteworthy that in addition to the fruit, another area of interest that has been growing in recent years is the production of pharmaceuticals. Mangaba leaves have important biocompounds for blood pressure (SILVA et al., 2011) and diabetes control (PEREIRA et al., 2015), and its latex has 
anti-inflammatory (MARINHO et al., 2011) and angiogenic properties (ALMEIDA et al., 2014). The extraction of medicinal interest biocompounds of this plant would add commercial value to this species, which could be used in the production of fruits and also in the extraction of drugs, opening a new perspective on the use of mangabeira.

The next parameter evaluated was type of scientific articles, if they were theoretical-descriptive or experimental articles. As a result, higher frequency of experimental articles was identified, $87.78 \%$, compared to theoretical-descriptive articles, $12.21 \%$ (Figure 4). An analysis of experimental works showed that they are very diverse and cover from fruit characterization to molecular studies (GANGA et al., 2010; MARTINS et al., 2012; SILVA et al., 2013; RODRIGUES et al., 2015; NOGUEIRA et al., 2015).

The larger number of experimental articles in relation to theoretical-descriptive articles was probably due to the agronomic and pharmacological focus of studies on the species. Although experimental articles were identified in greater number, many gaps need to be filled to make mangaba culture cost-effective. For example, studies addressing the genetic improvement of the species are needed, and our search identified eight articles assessing the genetic diversity of the population and only one on the selection of progenies. Studies on vegetative propagation, fertilization, management, plant science and plant health are also needed, and our search identified only 38 articles on these topics. Harvest, post-harvest and mangaba processing studies are also scarce, and our search identified only 19 articles. In addition to the low scientific production, there are few consulting actions conducted with farmers (producers and collectors) to disseminate and teach techniques of fruit management and marketing. These actions could transform mangaba production into a more rational and sustainable activity, consolidating it as a highly profitable agribusiness.

It is noteworthy that the lack of theoreticaldescriptive articles makes it difficult to characterize the geographic distribution of the species, which is known as Wallace impediment (Bini et al., 2006), and also contributes to the lack of taxonomic knowledge or Linnean impediment (WHITTAKER et al., 2005). Currently, there are discussions about the number of botanical varieties and the occurrence of $H$. speciosa synonymy (MONACHINO, 1945; KOCH et al, 2014), and this deficit in the taxonomic classification and little knowledge about mangaba distribution (Linnean and Wallacean, respectively) hampers the conservation of the species (BINI et al., 2006), which is already endangered (MANICA, 2002). In addition, basic theoretical-descriptive studies help in many cases in the development of methodologies to be used in experimental studies.

Another aspect being assessed was the geographical scope of the study. Most articles (74.8\%) were performed on a local scale, i.e., with restricted geographic distribution. Additionally, $25.2 \%$ of articles involved studies with varieties collected in broader geographic regions, on a regional scale. No studies with broad distribution spectrum have been identified, i.e., studies covering the entire area of the species occurrence (Figure 4).

The large number of articles conducted on a local scale may be because the use of mangabeira is mainly restricted to certain communities in northern and northeastern Brazil. Another possible explanation for this result may be related to the difficulty in obtaining $H$. speciosa samples outside its incidence area (Soares et al., 2005). Projects involving analysis of large geographical dispersion areas require greater financial resources, techniques for preservation of the material and longer time, but local and regional articles are more common because collections are more easily performed.

Another limiting factor in studies with perennial fruit trees such as mangaba is the long time to obtain results and the difficulty in obtaining financing by funding agencies in Brazil, since there are no companies in the private sector with interested in studying this culture. This result is associated with other parameters evaluated in this study, which was the type of research institution producing more knowledge about this species today. As a result, an increased interest in studying $H$. speciosa was observed by higher education institutions (universities) than by companies. Although the sum of articles published by universities has been considerably higher than those published by companies, EMBRAPA published the highest number of articles on the subject, with a total of 15 articles (Figure 5). It is noteworthy that both universities and EMBRAPA receive government funding for research with mangaba.

The origins of the first author and mangabeira samples were also evaluated in this study. The analysis of the first author's nationality showed that $97.7 \%$ were Brazilians, $1.52 \%$ Americans and $0.78 \%$ Portuguese. Figure 6 shows that for most studies, the first author belongs to institutions in the states of Minas Gerais, Sergipe and Goias. In relation to the collection site, the results showed that mangabas collected in the states of Goiás, Sergipe and Minas Gerais are the most studied and were those presenting the highest fruit production, a fact 
that favors obtaining the study material. Importantly, since mangaba is a highly perishable fruit, there are few studies on post-harvest fruit conservation (Campos et al., 2011).

The origin of studies is associated with regions of greater fruit production. IBGE data have shown that the state of Sergipe is the main producer, with $54.2 \%$ of production; followed by Bahia, with 15.5\%; Paraiba, with 13.1\%; Rio Grande do Norte, with 11.7\%; Alagoas, with 4.9\%; and Maranhao and Minas Gerais with $0.1 \%$ each in domestic production
(IBGE, 2010). One of the factors for the low fruit production in the state of Minas Gerais is the non-use of the production potential, by harvesting on small farms and because marketing is carried out by a single cooperative, while in Sergipe, harvest is organized, reaching a total of $93.7 \%$ pulp utilization, and fruits are sold in street markets and also at CONAB (National Supply Company). Production in Sergipe is 700 tons season / year and in Minas Gerais, it was only 200 tons season / year (Conab, 2014).

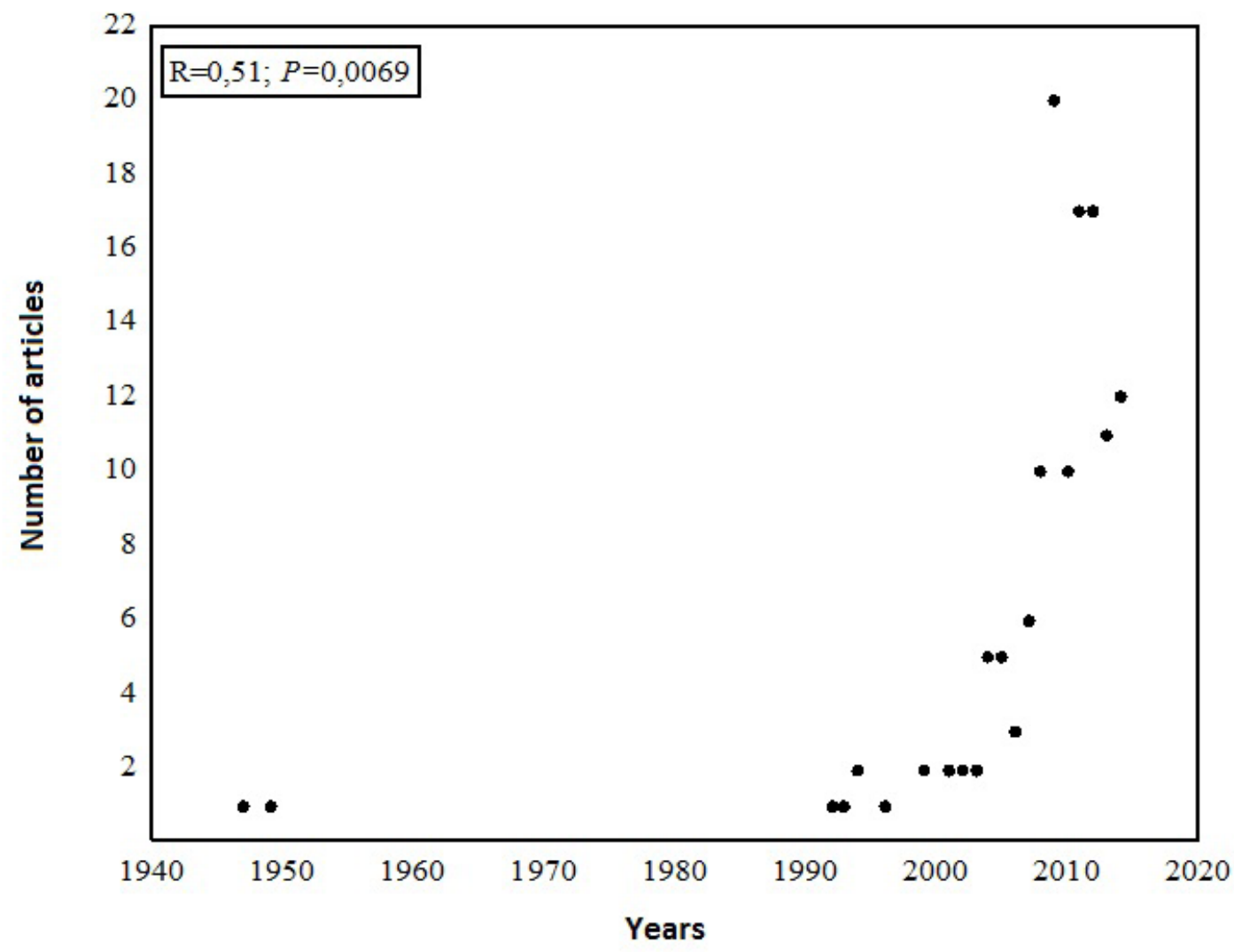

FIGURE 1-Pearson's correlation for temporal analysis between number of articles and publication years. 


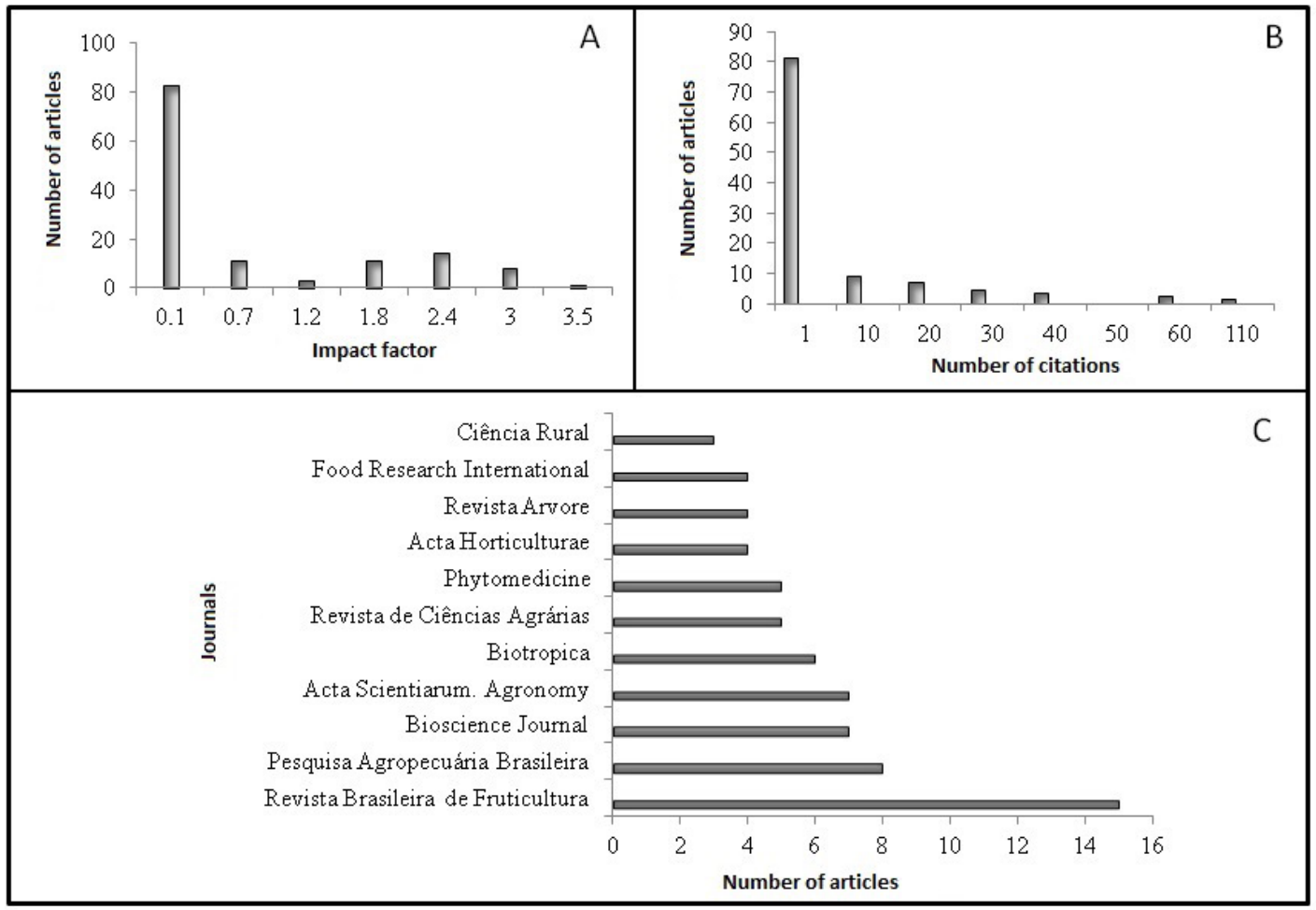

FIGURE 2- Impact factor of journals (A), number of citations (B) and main journals where articles on mangabeira have been published $(\mathrm{C})$.

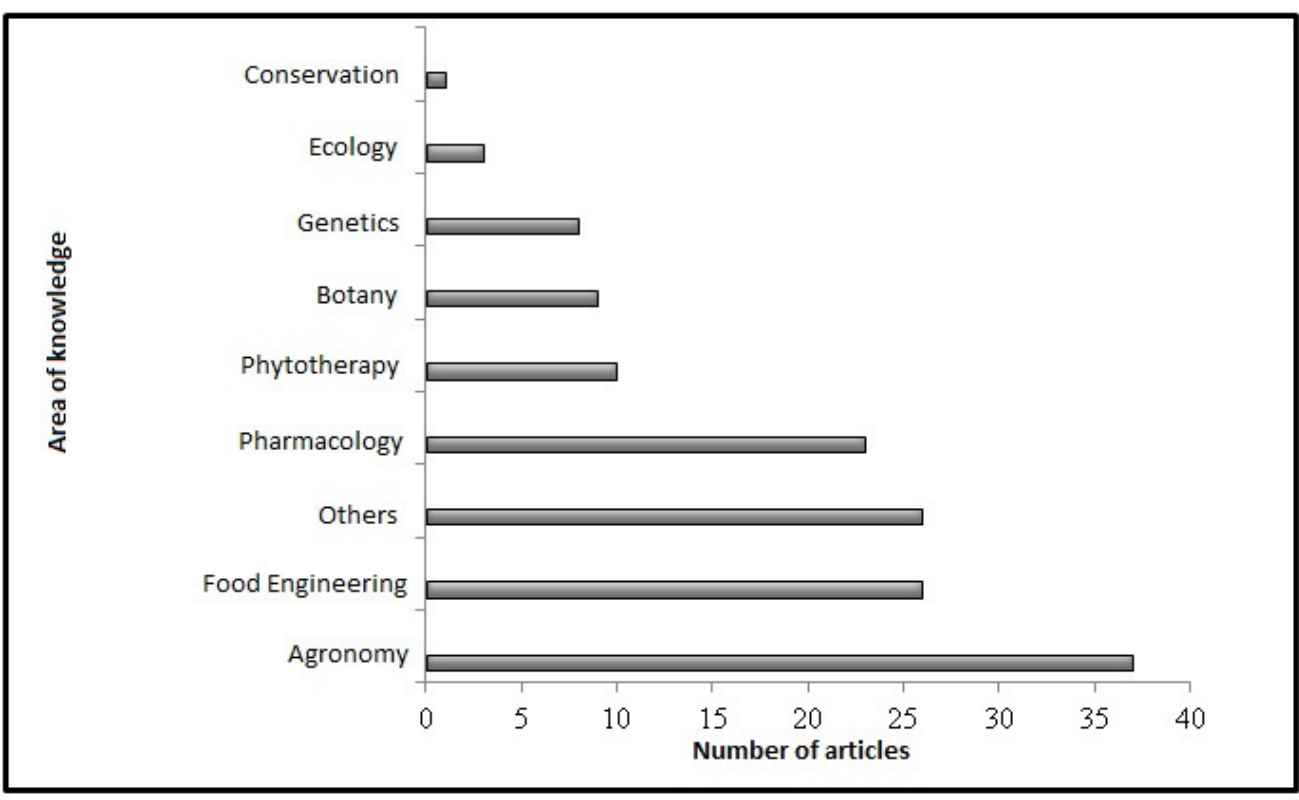

FIGURE 3 - Areas of knowledge in relation to the number of articles published on H. speciosa. 


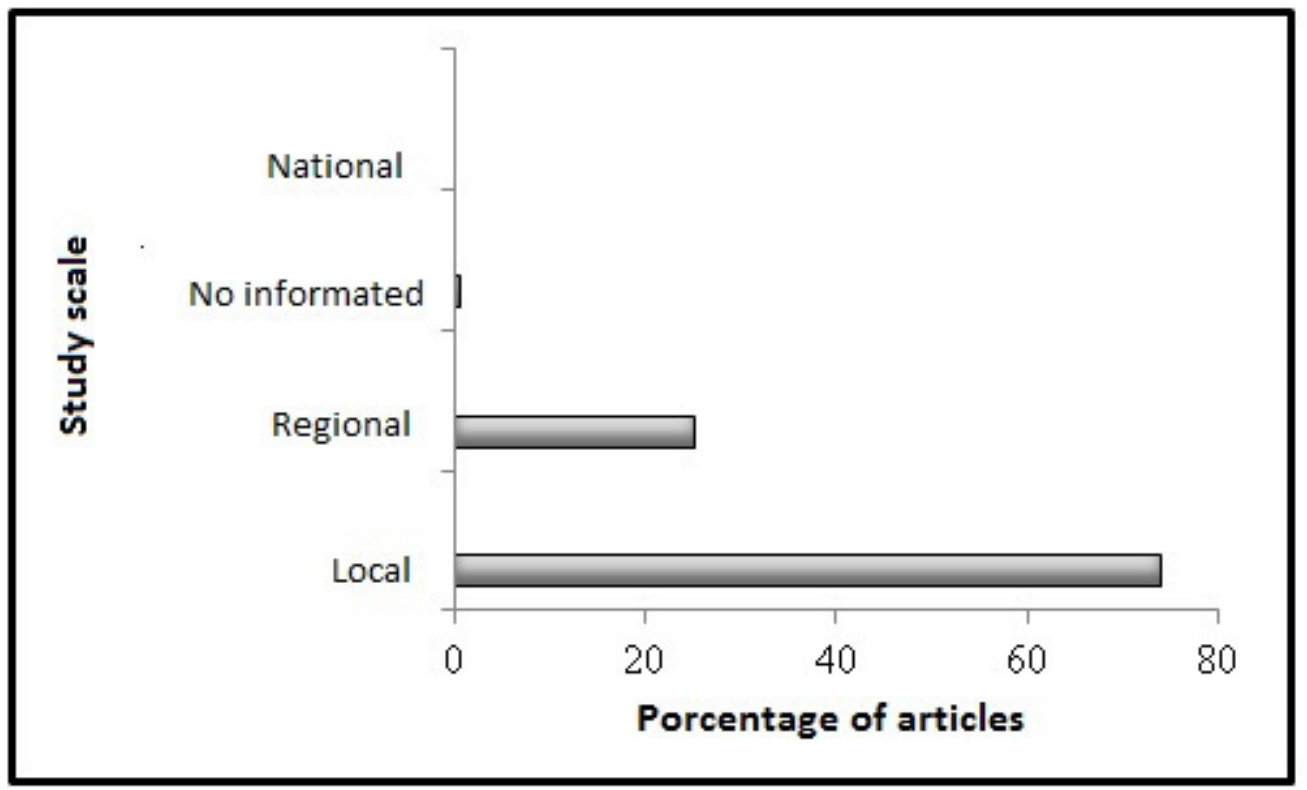

FIGURE 4- Study scale in relation to the number of articles.

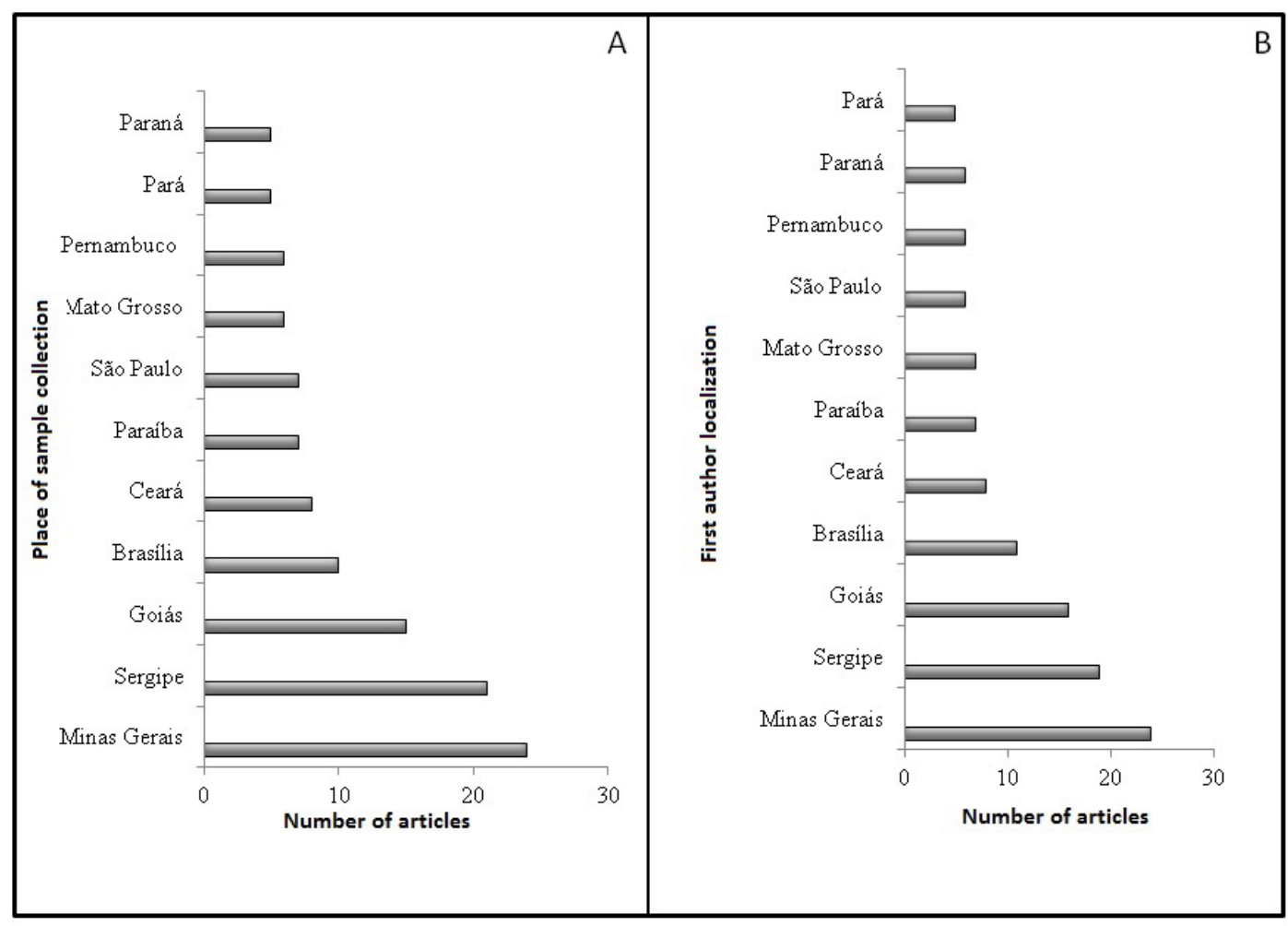

FIGURE 5-Type of institutions responsible for the study (A) and main institutions producing articles on the topic (B). 


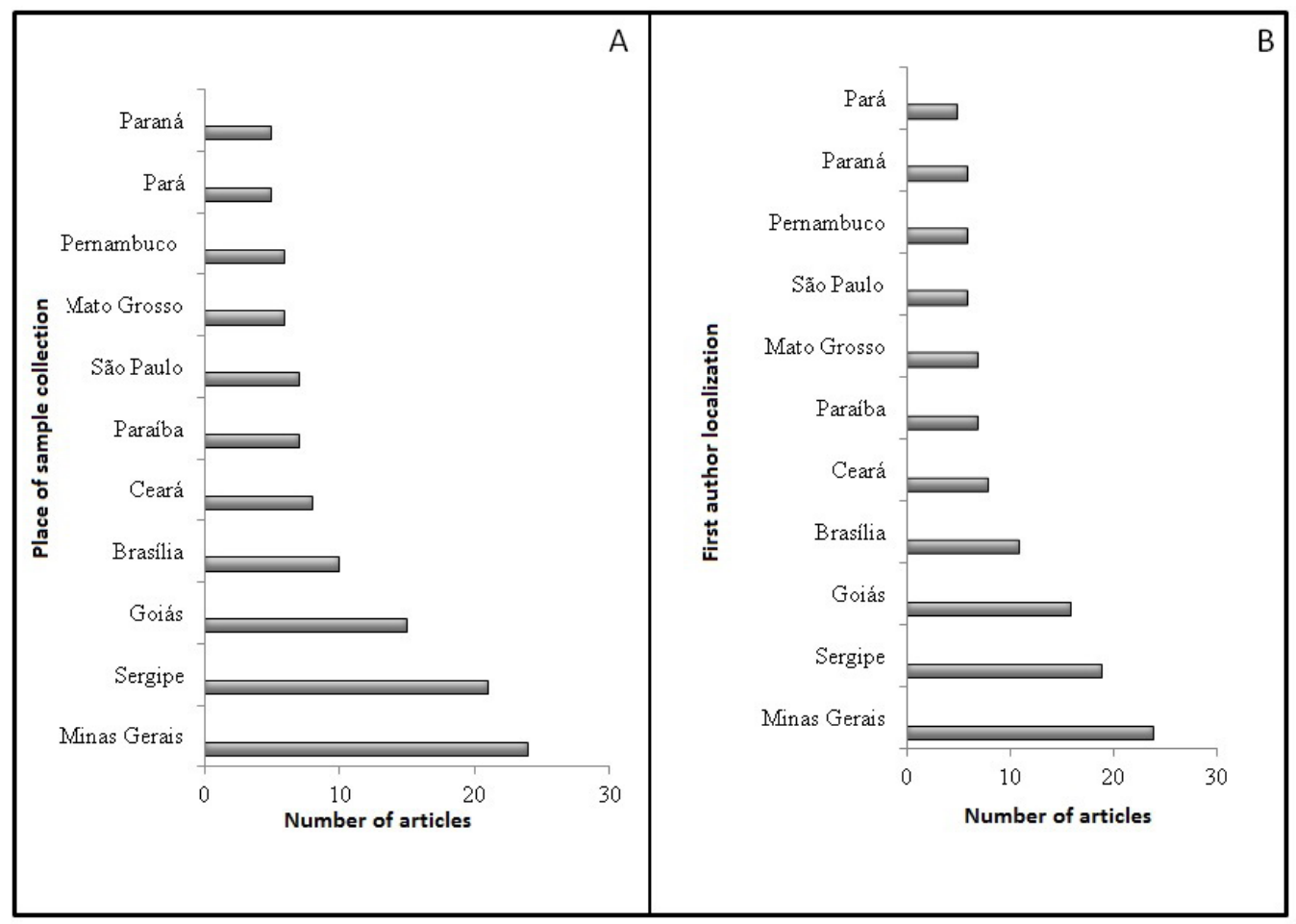

FIGURE 6- Origin of the first author (A) and place of data collection and study performance (B) .

\section{CONCLUSION}

This study reported the low scientific productivity regarding the $H$. speciosa species. Only 131 articles were published in the last 69 years. The following are among the trends identified that justify the results found: the increasing number of articles over the years; scientific publications in journals are preferably at national level; the main focus of study is associated with agronomic studies; the most frequent experimental approach is usually associated with populations of restricted geographical distribution; and scientific production mainly comes from higher education institutions. Furthermore, this study also allowed the identification of some gaps in knowledge about mangabeira, including: difficulty to describe and characterize botanical lines; lack of analysis of the genetic diversity of widely distributed populations; lack of projects for the management and conservation of the species; lack of description of cultivation, collection and preservation techniques; lack of identification of natural compounds responsible for its pharmacological activity. It is expected that the data generated in this study will serve to direct future studies on $H$. speciosa.

\section{ACKNOWLEDGMENTS}

The authors would like to thank the following Research Funding Agencies: FAPEG, CNPq, FNDCT, CAPES and FINEP. They also thank the Universidade Estadual de Goiás for granting of incentive to research (BIP).

\section{REFERENCES}

ALMEIDA, L.M.; FLORIANO, J.F.; RIBEIRO, T.P.; MAGNO, L.N.; Da MOTA, L.S.L.S.; PEIXOTO, N.; MRUÉ, F.; MELO-REIS, P.; LINO-JUNIOR, R. de S.; GRAEFF, C.F. de O.; GONÇALVES, P.J. Hancornia speciosa latex for biomedical applications: physical and chemical properties, biocompatibility assessment and angiogenic activity. Journal of Materials Science: Materials in Medicine, London, v.25, p.2153-2162, 2014.

BINI, L.M.; DINIZ - FILHO, J.A.F.; RANGEL, T.F.; BASTOS, R.P.; PINTO, M.P. Challenging Wallacean and Linnean shortfalls: knowledge gradients and conservation planning in a biodiversity hotspot. Diversity and Distributions, Oxford, v.12, n.5, p.475-482, 2006. 
CALIMAN, A.; PIRES, A.F.; ESTEVES, F.A.; BOZELLI, R.L.; FARJALLA, V.F. The prominence of and biases in biodiversity and ecosystem functioning research. Biodiversity and Conservation, London, v.19, n.3, p.651-664, 2010.

CAMPOS, R.P.; KNOCH, B.; HIANE, P.A.; RAMOS, M.I.L.; RAMOS-FILHO, M.M. 1-MCP on mangaba stored at ambiemtal temperature and $11^{\circ} \mathrm{C}$. Revista Brasileira de Fruticultura, Jaboticabal, v.33, n.1, p.206-212, 2011. Número especial.

CONAB. Conjuntura mensal - Mangaba (fruto). Disponível em: < http://www.conab.gov.br/ OlalaCMS/uploads/arquivos/14_10_10_17_14_06_ mangabasetembro2014.pdf $>$. Acesso em: $20 \mathrm{dez}$. 2014.

ENSSLIN, L.; WAICZYK, C.; CHAVES, L.C.; ENSSLIN, E.R. The process of evidencing the state of the art in scientific production management. TransInformação, Campinas, v.27, n.3, p.220-228, 2015.

FLORIANO, J. F.; NETO, F. C.; DA MOTA, L.S.L.S.; FURTADO, E.L.; FERREIRA, R.S.; BARRAVIERA, B.; GONÇALVES, P.J., ALMEIDA, L.M.; BORGES, F.A; HERCULANO, R.D.; GRAEFF, C. F.O. Comparative study of bone tissue accelerated regeneration by latex membranes from Hevea brasiliensis and Hancornia speciosa. Biomedical Physics \& Engineering Express, v. 2, p. $045007,2016$.

GANGA, R.M.D.; FERREIRA, G.A.; CHAVES, L.J.; NAVES, R.V.; NASCIMENTO, J.L. Characterization of fruits and trees from natural population of Hancornia speciosa Gomes of cerrado. Revista Brasileira de Fruticultura, Jaboticabal, v.32, n.1, p.101-103, 2010.

GUPTA, P.D.; DASWANI, P.G.; BIRDI, T.J. Approaches in fostering quality parmeters for medicinal botanical in Indian context. Indian Journal of Pharmacology, Mumbai v.46, n4, p.363-371.

IBGE - Instituto Brasileiro de Estatística. Produção da extração vegetal da silvicultura. Rio de Janeiro, 2010. v.25. Disponível em: <http://www.ibge.gov. br/home/estatistica/economia/pevs/2010/pevs2010. pdf>. Acesso em: 01 out. 2015.
KOCH, I.; RAPINI, A.; SIMÕES, A.O.; KINOSHITA, L.S.; SPINA, A.P.; CASTELLO, A.C.D. Apocynaceae in lista de espécies da flora do Brasil. Rio de Janeiro: Jardim Botânico. Disponível em: <http://reflora.jbrj.gov.br/jabot/floradobrasil/ FB15558>. Acesso em: 2014 out. 31.

LEDERMAN, I.E; SILVA Jr, J.F.; BEZERRA, J.E.F. Mangaba (Hancornia speciosa, Gomes). Jaboticabal Funep, 2000. p.35. (Série Frutas Nativas, 2).

MANICA, I. Frutas nativas, silvestres e exóticas 2: técnicas de produção de mercado: jeijoa, figo-daíndia, fruta pão, jaca, lichia, mangaba. Porto Alegre: Cinco Continentes, 2002. p.459-541.

MARINHO, D.G.; ALVIANO, D.S.; MATHEUS, M.E.; ALVIANO, C.S.; FERNANDES, P.D. The latex obtained from Hancornia speciosa Gomes possesses anti-inflammatory activity. Journal of Ethnopharmacology, Lausanne, v.135, p.530-537, 2011 .

MARTINS, G.V.; MARTINS, L.S.S; VEASEY, E.A., LEDERMAN, I.E., SILVA, E.F. Diversity and genetic structure in natural populations of Hancornia speciosa var. speciosa Gomes in northeastern Brazil. Revista Brasileira de Fruticultura, Jaboticabal, v.34, n.4, p.1143-1153, 2012.

MONACHINO, J.A. A revision of Hancornia (Apocynaceae). Lilloa, Tucuman, v.11, p.19-48, 1945.

MOTA, D.M.; SCHMITZ, H.; SILVA-JÚNIOR, J.F. Atores, canais de comercialização e consumo da mangaba. Economia e Sociologia Rural, Brasília, DF, v. 46, n.1, p.121-140, 2008.

NOGUEIRA, C.A.; STAFUZZA, N.B.; RIBEIRO, T.P.; PRADO, A.D.L.; MENEZES, I.P.P.; PEIXOTO, N.; GONÇALVES, P.J.; ALMEIDA, L.M. Intraspecific differentiation of Hancornia speciosa revealed by simple sequence repeat and random amplified polymorphic DNA markers. Genetics and Molecular Research, v. 14, p. 15996-16005, 2015. 
PEREIRA, A.C.; PEREIRA, A,B.; MOREIRA, C.C.; BOTION, L.M.; LEMOS, V.S.; BRAGA, F.C.; CORTES, S.F. Hancornia speciosa Gomes (Apocynaceae) as potential anti-diabetic drug. Journal of Ethnopharmacology, Laussanne, v.161, p.30-35, 2015.

R CORE TEAM. R: a language and environment for statistical computing. Vienna: R Foundation for Statistical Computing. 2013. Disponível em: < $\underline{\text { http:// }}$ www.R-project.org/>.

REZENDE, C. F. A.; NAVES, R. V.; CHAVES, L. J.; MOURA, N.F.; BERNARDES, T. G. Caracterização de ambientes com alta densidade e ocorrência natural de mangabeira (Hancornia speciosa Gomes) no Cerrado. In: SIMPÓSIO BRASILEIRO SOBRE A CULTURA DA MANGABA, 2003, Aracaju. Anais... Aracaju: Embrapa Tabuleiros Costeiros, 2003.

RODRIGUES, A.J.; YAMAGUSHI, A.T.; CHAVES, L.J.; COELHO, A.S.; LIMA, J.S.; TELLES, M.P. Development of microssatelite markers for Hancornia speciosa Gomes (Apocynaceae). Genetics and Molecular Research, Ribeirão Preto, v.13, n.3, p.7274-7278, 2015.

SILVA JÚNIOR, J.F da; LEDÓ, A.S. A cultura da mangaba. Aracajú: EMBRAPA Tabuleiros Costeiros, 2006, 253 p.

SIlVA, G. C.; BRAGA, F. C.; LIMA, M. P.; PESQUERO, J. L.; LEMOS, V.S.; CORTES, S. F. Hancornia speciosa Gomes induces hypotensive effect through inhibition of ACE and increase on NO. Journal of Ethnopharmacology, Laussanne, v.137, p.709-711, 2011.
SILVA, S.A., CRZ, E.M.O., REIS, R.V.R., FERREIRA, C.F., PASSOS, A.R. Morphological and molecular characterization of mangaba genotypes. Revista Brasileira de Fruticultura, Jaboticabal, v.35, n.4, p.1093-1100, 2013.

SOARES, F. P.; PAIVA R.; NOGUEIRA, R. C.; OLIVEIRA, L. M. de.; SILVA, D. R. G; PAIVA, P.D. de O. Cultura da mangabeira (Hancornia speciosa Gomes). Boletim Agropecuário, Lavras, n.67, p.1$12,2005$.

SOUZA, F. G. D.; FIGUEIREDO, R. W. D.; ALVES, R. E.; MAIA, G. A.; ARAÚJO, I. A. D. Postharvest quality of fruits from different mangabeira clones (Hancornia speciosa Gomes).

Ciência e Agrotecnologia, Lavras, v.31, n.5, p.14491454, 2007.

VIEIRA-NETO, R.D. Mangaba: alta rentabilidade atria produtores, Zoonews, v.5, ago, 2007. Disponível em: <http://www.boletimpecuario.com.br/notes/ noticia.php?not=ancora2502. Boletimpecuario $>$.

WHITTAKER, R. J.; ARAÚJO, M. B.; JEPSON, P.; LADLE, R. J.; WATSON, J. E.; WILLIS, K.

J. Conservation biogeography: assessment and prospect. Diversity and Distributions, Oxford, v.11, n.1, p.3-23, 2005 